\title{
Vacuum microwave drying of acerola residue: Effects of pre-treatment and operating variables on main bioactive compounds
}

\author{
Geraldo D. R. Nogueira
}

Universidade Federal de Uberlandia

Priscila B. Silva

Federal University of Maranhao: Universidade Federal do Maranhao

Glaucia F. M. V. Souza

Universidade Federal de Uberlandia

Claudio R. Duarte

Universidade Federal de Uberlandia

Marcos A.S. Barrozo ( $\nabla$ masbarrozo@ufu.br)

Universidade Federal de Uberlandia https://orcid.org/0000-0002-8873-162X

\section{Research Article}

Keywords: acerola waste, hybrid drying, bioactive compounds, microorganisms

Posted Date: February 21st, 2022

DOI: https://doi.org/10.21203/rs.3.rs-1292993/v1

License: (9) This work is licensed under a Creative Commons Attribution 4.0 International License. Read Full License 


\section{Abstract}

Even though the residue from the processing of acerola (Malpighia emarginata D.C.) has significant amounts of vitamin $\mathrm{C}$ and other bioactive compounds at the same level as the pulp and the juice of this fruit, it also has a high moisture content level $(>80 \%)$. In this work, the drying performance of acerola residue in a microwave oven combined with a vacuum environment was investigated. The effect of pretreatment with ethanol on this drying process was successfully analyzed, together with the influence of main process variables on the moisture removal and the main bioactive compounds of this by-product of the fruit industry. The values obtained for the bioactive compounds after drying could be classified as intermediate concentrations, thus showing a good potential to be used as food additives. The growth of mesophilic bacteria, molds, and yeasts in acerola residues was not observed for the dried material at a final moisture content below $26.2 \%(w b)$.

\section{Statement Of Novelty}

The high amounts of vitamin $\mathrm{C}$ and bioactive compounds with antioxidant activity in the residues from the processing of acerola justify the growing interest from the fruit processing industry in the development of appropriate techniques for its best use. In this work, a hybrid technology - vacuum microwave - and ethanol pre-treatment, was successfully used in the acerola waste drying. We achieved a shorter drying time and lower product surface temperature, while improved the moisture removal compared to other drying techniques used for this material. This technology is able to maintain the quality of acerola residues, prolonging their shelf life and providing safe moisture and water activity levels.

\section{Introduction}

Acerola (Malpighia emarginata D.C.) is a fruit native to tropical America that has attracted interest from the fruit processing industry for consumption in the form of juice, jelly and compote due to its pleasant flavor and the high levels vitamin $\mathrm{C}$ and other bioactive compounds, such as tocopherols, carotenoids, flavonoids and phenolic compounds [1]. However, it is estimated that $40 \%$ of the processed volume of this fruit turn into waste, for example, seeds, kernels and bagasse, which is generally discarded or underutilized, causing losses of raw material and negative environmental impact [1, 2].

Some studies have shown that the residues from the processing of acerola can contain high amounts of bioactive compounds with antioxidant activity generally associated with the prevention of degenerative diseases related to aging, such as cancer and cardiovascular disease $[1,3,4]$. These aspects, along with the increasing global interest in environmentally-friendly technologies, justify the interest in a better utilization of these wastes [5-7]. However, these materials have a high moisture content level (>80\%), which limits and complicates their transport, storage, and shelf life by non-enzymatic, enzymatic, or microbial reactions that alter the product quality, including deterioration, safety, and functional properties $[1,8,9]$. Thus, it is necessary to submit these residues to an efficient dehydration process. In this way, 
combined drying techniques appears as an alternative to conserve the properties and the bioactive compounds present in this and other residues $[10,11]$. It is known that the dried product has great potential to generate food additives, which in turn will minimize malnutrition and hunger in last developed countries where it is produced [12], thus providing a better use of such residues, in addition to representing a great opportunity to improve food security.

The drying of granular materials has been extensively studied using various types of dryers [5, 12-22]. However, acerola residues present high values of static and dynamic angles of repose, which makes drying in moving bed dryers more difficult. In contrast, some studies have shown that packed bed dryers are unsuccessful in maintaining the homogeneous properties of the product along the bed [23-25]. A solution to this limitation in terms of energy efficiency, process economy and product quality may come from hybrid drying systems and the use of pretreatments $[4,11,26]$. Some studies have proposed the combination of different drying techniques, such as hot air-microwave, microwave-vacuum, and hot airinfrared $[4,24-26]$. Among these, microwave drying combined with vacuum has shown to be promising, with lower processing time, more uniform heating, safe handling, easy operation, and energy efficiency [26-29]. The most important characteristic of microwave heating is volumetric heating, where the materials can absorb microwave energy directly and generate an internal heat flux, which is quite different from conventional heating [30]. This volumetric heating combined with vacuum drying could produce a more open-porous structure that facilitates the diffusion of gases through the pores [31]. The benefits of microwave vacuum drying include increased thermal efficiency, reduction in drying time without significant damage to the final product quality, possibility of preservation of the bioactive compounds [32-34], and the obtaining of adequate moisture for a safe storage, consequently preventing or reducing the growth of microorganisms $[8,35,36]$.

The hybrid drying system can also be used in conjunction with some pretreatment to enhance the drying efficiency and product quality [37-39]. The use of ethanol in pre-treatments has been investigated aiming to reduce the initial moisture content or to modify the material tissue structure in a way that the drying time can become lower $[40,41]$. In addition, ethanol is a well-accepted organic compound in the food industry, being considered a safe substance [42].

The present work aimed to investigate the use of a microwave vacuum dryer associated with a pretreatment with ethanol in the drying process of acerola residues. The effects of operating variables on the drying performance and the product quality in terms of bioactive compounds content (ascorbic acid, phenolics and flavonoids) were analyzed, and the appropriate range of moisture for a safe storage that prevents the growth of microorganisms was identified.

\section{Material And Methods}

\section{Material}


The acerola waste used in this work was provided by a juice processing industry (FrutPres Company, Minas Gerais-SP, Brazil). The material was packed in sealed dark-polyethylene bags and stored frozen at $-18^{\circ} \mathrm{C}$. The samples were removed from the freezer 24 hours prior to drying and then placed in a refrigerator at $5^{\circ} \mathrm{C}$ to thaw. The initial moisture of the acerola residues was $80.84 \pm 1.31 \%$ wet base (wb).

\section{Experimental apparatus}

The drying tests were carried out in a microwave oven (Panasonic model NNSF560WRUK) with a frequency of $2450 \mathrm{MHz}$ and a maximum power of $800 \mathrm{~W}$, adapted to operate with vacuum. The system consisted of a vacuum pump connected to a flask filled with silica gel and a hose inserted into the upper cover of the microwave oven extending into the drying chamber (vacuum chamber).

\section{Operating conditions and methodology}

Different levels of microwave power (114, 229, 399 and $513 \mathrm{~W})$ and vacuum $(0,100,200,300$ and 400 $\mathrm{mmHg}$ ) were used in the experiments. The experimental runs were performed randomly in order to minimize systematic errors.

For the drying tests, the residue $(60.0 \pm 0.5 \mathrm{~g})$ was first placed in the drying chamber, followed by vacuum application. Then, the microwave power was programmed for the operating conditions established, and the residues were dehydrated to the moisture of $10.0 \pm 1.5 \%(\mathrm{wb})$. An infrared thermometer (Minipa, model MT-395) determined the temperature of the samples and the moisture content of the samples was determined by the oven method $\left(105 \pm 3^{\circ} \mathrm{C}\right.$ for $\left.24 \mathrm{~h}\right)$.

\section{Pretreatment with ethanol (EP)}

The pretreatment was performed with $93.2^{\circ} \mathrm{GL}$ ethanol (EP). The acerola residues were immersed in ethanol at the ratio of $4 \mathrm{~L}$ of ethanol to $1 \mathrm{~kg}$ of residues for $5 \mathrm{~min}$ [43]. The residues were allowed to sit for $1.5 \mathrm{~h}$ before drying. The same drying conditions showed in the previous item were also used with the samples submitted to pretreatment.

\section{Drying kinetics}

All moisture data obtained during the experiments were converted into moisture ratio $(M R)$ according to Eq (1):

$$
M R=\frac{\left(\mathrm{M}-\mathrm{M}_{\mathrm{eq}}\right)}{\left(M_{0}-\mathrm{M}_{\mathrm{eq}}\right)}
$$

1

where $M$ is the moisture content at any time, $M_{e q}$ is the equilibrium moisture content, and $M_{0}$ is the initial moisture content. 
The value of $M_{e q}$ (Eq. 2) was calculated using the Sigma-Copace equation, which was the equation that best fitted the equilibrium moisture data of acerola residues in our previous work [11].

$$
M_{\mathrm{eq}}=\exp [a-b T+\operatorname{cexp}(R H)]
$$

2

where $R H$ is the relative humidity and are $\mathrm{a}=-0.074, \mathrm{~b}=0.013^{\circ} \mathrm{C}^{-1}$, and $\mathrm{c}=1.578$.

A great number of empirical and semi-empirical equations have been used to describe the drying kinetics of biological materials $[14,44,45]$. Table 1 presents the drying kinetic equations evaluated in this paper. The parameters of these models were estimated by non-linear regression. We selected the kinetic model that best predicted the drying kinetics considering an appropriate statistic criterium $[46,47]$.

Table 1

- Drying kinetics equations.

\begin{tabular}{|ll|}
\hline Model & Reference \\
\hline$M R=\exp (-k t)$ & Lewis (1921) \\
\hline$M R=\exp \left(-k t^{n}\right)$ & Page (1949) \\
$M R=A \exp (-k t)+\frac{1}{9} \exp (-k t)$ & Henderson e Henderson (1968) \\
\hline$M R=\exp \left[-(k t)^{n}\right]$ & Overhults et al (1973) \\
\hline$M R=A \exp (-k t)$ & Brooker et al. (1974) \\
\hline
\end{tabular}

\section{Quality evaluation}

Bioactive compounds were quantified in the acerola residues before and after drying, namely, ascorbic acid content (AA), total phenolic content (TPC) and total flavonoid contents (TFC). All bioactive compounds were expressed in dried basis, including the ones for fresh residues. All analyses were performed in triplicate. Significant differences between means were evaluated by one-way analysis of variance (ANOVA) and Tukey's multiple-range test $(\mathrm{p}<0.05)$.

\section{Ascorbic acid content (AA)}

The ascorbic acid content (AA) was determined according to Dürüst et al [48]. This method involves the reduction of 2.6-dichlorophenol-indophenol by ascorbic acid. Standard ascorbic acid solutions from 5 to $70 \mathrm{mg} / \mathrm{mL}$ were used for curve construction. All results were expressed in milligrams of ascorbic acid per $100 \mathrm{~g}$ of sample (dry matter).

\section{Total phenolic content (TPC)}

The total phenolic content was determined using the Folin-Ciocalteu method [49]. The Folin-Ciocalteu reagent is a solution of complex polymeric ions formed by heteropolyacids and phosphomolybdic- 
phosphotungstic acids. This reagent promotes the oxidation of phenolates and the reduction of acids to a blue complex (W, Mo). Gallic acid monohydrate (99\%) was used as standard. Absorbance was recorded at $622 \mathrm{~nm}$.TPC was expressed as milligrams of gallic acid equivalent (GAE) per $100 \mathrm{~g}$ of sample (dry matter).

\section{Total flavonoid content (TFC)}

The same extracts obtained in the TPC analysis were used in the determination of total flavonoid content. The colorimetric method described by Zhishen et al. [50] was applied with rutin hydrate (94\%) as standard. Absorbance was recorded at $450 \mathrm{~nm}$. The results were expressed as milligrams of rutin per 100 $\mathrm{g}$ of sample (dry matter).

\section{Water activity (Aw)}

Water activity $\left(A_{w}\right)$ was determined using a Novasina thermoconstanter (model Labswift-aw, Novasina, Switzerland). All measurements of water activity were also performed in triplicate.

\section{Statistical treatment}

The drying kinetic equations analyzed in this work were fitted to the experimental data using nonlinear regression [51]. The effects of the independent variables (microwave power and vacuum) on the drying kinetic parameters, i.e. the drying kinetic constant $(k)$ and " $n$ " were quantified using regression technique, also considering the interaction and quadratic effects. In these regressions, the microwave power $(P)$ and vacuum $(\mathrm{V})$ were placed in coded form using the following equations (Eq. 3):

$x_{1}=\frac{P(W)-300}{170} ; x_{2}=\frac{V(\mathrm{mmHg})-200}{100}$ (3)

Parameters with a $p$-value greater than $10 \%$ were disregarded, and the respective variables, interaction or qudratic effects were considered not significant.

The model that best represented the experimental data was selected considering the significance of the parameters, determination of coefficient $\left(R^{2}\right)$, reduced qui-square $\left(\chi^{2}\right)$ and root mean square residuals (RMSE) $[1,47,52]$. The higher $R^{2}$, lower $\chi^{2}$ and RMSE values are related to the goodness of fit. The $\chi^{2}$ and $R M S E$ can be calculated by using Equations 4 and 5, respectively. The statistical analyses were performed using the software Statistica 7.0.

$$
\chi^{2}=\frac{\sum_{i=1}^{N}\left(M R_{e x p, i}-M R_{p r e, i}\right)^{2}}{N-Z}
$$

$$
R M S E=\left[\frac{1}{N} \sum_{I=1}^{N}\left(M R_{e x p, i}-M R_{p r e, i}\right)^{2}\right]^{1 / 2}
$$


In these equations, $N$ is the number of observations, $z$ is the number of constants, $M R_{\text {exp }}$ and $M R_{\text {pre }}$ are the experimental and predicted moisture ratios, respectively.

\section{Microbiological analysis}

In order to evaluate the growth of aerobic mesophilic bacteria $\left(35-37^{\circ} \mathrm{C}\right)$, molds and yeasts in the material, different moisture ranges were used $(3.7-66.9 \%$, wb). The acerola residue was dehydrated by vacuum microwave drying at a microwave power of $229 \mathrm{~W}$ and $200 \mathrm{mmHg}$ of vacuum. After dehydration, the residue was stored in vacuum-sealed units and protected from light.

The sample dilutions were prepared according to the standard described by International Organization for Standardization - ISO 6887-4 [53], which specifies sample preparation rules and decimal dilutions for microbiological analysis of food products. In this methodology, the dehydrated material must be left at rest with diluent (sterile peptone water $0.1 \%$ ) for $30 \pm 5 \mathrm{~min}$ to recover from injuries or stress caused by processing. After this period, the volume is transferred to subsequent dilutions. Serial dilutions were performed by adding $1 \mathrm{~mL}$ of the previous dilution solution to a test tube with $9 \mathrm{~mL}$ of $0.1 \%$ sterile peptone water, resulting in a $10^{-1}$ dilution. The mixture was stirred for $1 \mathrm{~min}$ for complete homogeneity. The procedure was repeated taking $1 \mathrm{~mL}$ of the previous dilution up to the $10^{-5}$ dilution.

For the determination of mesophilic bacteria, the culture medium used was PCA (Plate Count Agar). For the counting, we used the spread plate methods described by Silva et al. [54]. Triplicate plates were prepared in a laminar flow chamber using approximately $20 \mathrm{~mL}$ of PCA medium and $0.1 \mathrm{~mL}$ of each dilution. After a $48 \mathrm{~h}$ incubation time at $36^{\circ} \mathrm{C}$, the plates with Colony Forming Units (CFU) were counted between 30 and 300 . The arithmetic mean was multiplied by the respective dilution factor and the concentration was determined in $\mathrm{CFU} \mathrm{g}^{-1}$ acerola residue.

To count the molds and yeasts, a methodology similar to that previously described was applied. However, the culture medium used was PDA (Potato Dextrose Agar) and the incubation time was 3 to 5 days at a temperature of $30^{\circ} \mathrm{C}[55]$.

\section{Results And Discussion}

\section{Drying kinetics}

Among the analyzed kinetic equations, the Overhults equation was the one that presented the best statistical results, i.e., highest $\mathrm{R}^{2}$, lowest $\chi^{2}$ and RMSE values, in addition to all estimated parameters with $\mathrm{p}$-level lower than 0.1. Therefore, this equation was chosen to represent the kinetics of acerola residue drying in vacuum microwave with and without ethanol pretreatment (EP). Table 2 shows the fitted parameters of the Overhults equation as well as the $\mathrm{R}^{2}, \chi^{2}$ and RMSE values for the different operating conditions. 
Table 2

- Parameters of the Overhults equations for vacuum microwave drying without and with pre-treatment $(\mathrm{EP})$.

\begin{tabular}{|c|c|c|c|c|c|c|c|}
\hline \multirow[t]{2}{*}{ Sample } & \multicolumn{2}{|c|}{ Condition } & \multicolumn{2}{|c|}{ Parameters } & \multirow[t]{2}{*}{$\mathrm{R}^{2}$} & \multirow[t]{2}{*}{$\chi^{2}$} & \multirow[t]{2}{*}{ RMSE } \\
\hline & $\begin{array}{l}\text { Power } \\
\text { (W) }\end{array}$ & $\begin{array}{l}\text { Vacuum level } \\
(\mathrm{mmHg})\end{array}$ & $k$ & $\mathrm{n}$ & & & \\
\hline \multirow[t]{7}{*}{$\begin{array}{l}\text { Without } \\
\text { EP }\end{array}$} & 229 & 100 & $\begin{array}{l}0.050 \pm \\
0.001\end{array}$ & $\begin{array}{l}2.254 \pm \\
0.029\end{array}$ & 0.9931 & 0.0009 & 0.0607 \\
\hline & 229 & 200 & $\begin{array}{l}0.052 \pm \\
0.001\end{array}$ & $\begin{array}{l}2.240 \pm \\
0.024\end{array}$ & 0.9968 & 0.0004 & 0.0445 \\
\hline & 229 & 300 & $\begin{array}{l}0.055 \pm \\
0.001\end{array}$ & $\begin{array}{l}2.122 \\
\pm 0.009\end{array}$ & 0.9985 & 0.0002 & 0.0264 \\
\hline & 229 & 400 & $\begin{array}{l}0.058 \pm \\
0.001\end{array}$ & $\begin{array}{l}2.122 \pm \\
0.009\end{array}$ & 0.9937 & 0.0009 & 0.0497 \\
\hline & 114 & 200 & $\begin{array}{l}0.025 \pm \\
0.001\end{array}$ & $\begin{array}{l}2.148 \pm \\
0.153\end{array}$ & 0.9974 & 0.0003 & 0.0346 \\
\hline & 399 & 200 & $\begin{array}{l}0.098 \pm \\
0.002\end{array}$ & $\begin{array}{l}2.185 \pm \\
0.041\end{array}$ & 0.9981 & $<10^{-4}$ & 0.0049 \\
\hline & 513 & 200 & $\begin{array}{l}0.132 \pm \\
0.001\end{array}$ & $\begin{array}{l}1.734 \pm \\
0.076\end{array}$ & 0.9962 & $<10^{-4}$ & 0.0003 \\
\hline \multirow[t]{7}{*}{ With EP } & 229 & 100 & $\begin{array}{l}0.063 \pm \\
0.001\end{array}$ & $\begin{array}{l}1.982 \pm \\
0.023\end{array}$ & 0.9874 & 0.0015 & 0.0668 \\
\hline & 229 & 200 & $\begin{array}{l}0.067 \pm \\
0.001\end{array}$ & $\begin{array}{l}1.947 \pm \\
0.029\end{array}$ & 0.9928 & 0.0009 & 0.0519 \\
\hline & 229 & 300 & $\begin{array}{l}0.071 \pm \\
0.001\end{array}$ & $\begin{array}{l}1.848 \pm \\
0.048\end{array}$ & 0.9967 & 0.0004 & 0.0348 \\
\hline & 229 & 400 & $\begin{array}{l}0.076 \pm \\
0.001\end{array}$ & $\begin{array}{l}1.816 \pm \\
0.085\end{array}$ & 0.9939 & 0.0008 & 0.0522 \\
\hline & 114 & 200 & $\begin{array}{l}0.037 \pm \\
0.001\end{array}$ & $\begin{array}{l}2.035 \pm \\
0.002\end{array}$ & 0.9993 & 0.0001 & 0.0204 \\
\hline & 399 & 200 & $\begin{array}{l}0.134 \pm \\
0.006\end{array}$ & $\begin{array}{l}1.969 \pm \\
0.034\end{array}$ & 0.9996 & $<10^{-4}$ & 0.0049 \\
\hline & 513 & 200 & $\begin{array}{l}0.174 \pm \\
0.008\end{array}$ & $\begin{array}{l}1.844 \pm \\
0.021\end{array}$ & $>0.9999$ & $<10^{-4}$ & 0.0003 \\
\hline
\end{tabular}

The acerola residue pretreated with ethanol presented the highest values of kinetic constant $(k)$ for all drying conditions (Table 2), being on average 33\% higher than that without pretreatment. This result indicates that higher drying rates can be obtained when samples undergo ethanol pretreatment.

Figure 1 illustrates the drying curves of non-treated acerola residue (Fig. 1a) and the sample pretreated with ethanol (Fig. 1b) using $200 \mathrm{mmHg}$ of vacuum applied at different microwave powers, evidencing the 
significant effect of pretreatment and microwave power on the drying behavior.

- Figure 1

\section{Surface temperature profile}

It is reported that the bioactivity of the dehydrated product is directly influenced by the material temperature reached during the drying process [56]. Therefore, the effect of the drying conditions on the temperature variation of the material also requires a special attention. Fig. 2 shows the temperature profiles of the acerola residues during the drying process at different vacuum levels until reaching the final moisture content of $10.0 \pm 1.5 \%$ (wb). The samples, both non-treated (Fig. 2a) and pretreated with ethanol (Fig. 2b), were dehydrated at $229 \mathrm{~W}$. It is possible to observe that during vacuum microwave drying, the sample temperature rapidly increases until it reaches a temperature plateau that remains constant for some time. At this stage, the product temperature is the saturation temperature of the water present in the food at the pressure to which it is submitted. The constant temperature is close to the water boiling temperature at the given pressure [57].

It can be seen that by increasing the vacuum from 100 to $400 \mathrm{mmHg}$ the temperature reduced approximately $20^{\circ} \mathrm{C}$ of the final temperature achieved for both residues (non-treated and pretreated with ethanol). It also can be noticed that the time required before achieving the constant temperature was approximately $12.5 \mathrm{~min}$ for the sample pretreated with ethanol (Fig. 2-b), while the non-treated sample took around 5 min (Fig. 2-a). However, the final temperature of the sample pretreated with ethanol was approximately $3^{\circ} \mathrm{C}$ lower than the one that did not receive pretreatment. This occurred due to the difference between the physical properties of ethanol and water, that is, ethanol has lower dielectric loss factor $\left(1.64\right.$ at $\left.25^{\circ} \mathrm{C}\right)$ than water $\left(12\right.$ at $\left.25^{\circ} \mathrm{C}\right)$ [58].

- Figure 2

\section{Bioactive compounds}

The quality of the dried product can be significantly affected by the operating conditions, as well as by the temperature reached by the material and the time used in the process [59]. In this study, the ascorbic acid (AA), the total phenolic content (TPC) and the total flavonoid content (TFC) of acerola residues in natura and dehydrated in vacuum microwave process were quantified. The initial values (fresh sample) of these bioactive compounds were as follows: AA: $4650 \pm 230 \mathrm{mg}$ of ascorbic acid (AA) $100 \mathrm{~g} \mathrm{~g}^{-1}$ (dry basis); TPC: $1495 \pm 45$ GAE 100. $\mathrm{g}^{-1}$ (dry basis); and TFC: $4605.44 \pm 97.43 \mu \mathrm{g}$ rutin 100. $\mathrm{g}^{-1}$ (dry basis). The effects of vacuum level, microwave power output and ethanol pretreatment on the main bioactive compounds can be visualized in Figs. 3, 4, and 5.

\section{- Figure 3}

Figure 3-a shows that the difference in AA after drying at different microwave powers was very low. The same behavior was reported by Alibas and Köksal [60], who evaluated the ascorbic acid content after drying mellow leaves in microwave. However, the AA values for the samples pretreated with ethanol were 
higher than those obtained for the samples without pretreatment. On average, there was an increase of $74.46 \%$ in AA for the samples submitted to pretreatment.

Figure 3-b reveals that the increase of vacuum applied leads to a positive effect on AA until $300 \mathrm{mmHg}$. It happens because the vacuum reduces the amount of oxygen in contact with the sample, which prevents ascorbic acid degradation by oxidation [61]. A similar behavior was reported by Thomkapanich et al. [62], who dehydrated banana slices under vacuum. However, when $400 \mathrm{mmHg}$ of vacuum was applied, there was a slight reduction in AA since the lower temperatures of these conditions may have inhibited the deactivation of the enzyme responsible for degrading the ascorbic acid [59].

Figures 4 and 5 show the results of TPC and TFC obtained at different microwave powers and vacuum levels of samples submitted or not to ethanol pretreatment. It can be observed in Fig. 4 that the effect of microwave power and vacuum applied on TPC was very low, and in some conditions negligible. The same trend was observed by Wojdylo et al. [63] during microwave drying of strawberry. On the other hand, the effect of pretreatment with ethanol was found to be significant, but with a negative effect since an average reduction of $46.58 \%$ was observed in TPC for the pretreated samples. This behavior can be explained by the solvent action of ethanol, extracting phenolic compounds [64].

- Figure 4

As illustrated in Fig. 5, there was no clear effect of any of the studied variables on TFC, and in most conditions the TFC values were statistically equal.

The values obtained for TPC and TFC after drying under the different conditions used in this study can be classified as intermediate concentrations, according to the classification of Vasco et al. [65], thus showing a good potential to be used as food additives.

- Figure 5

\section{Microbiological and water activity $\left(A_{w}\right)$ analysis}

The samples dehydrated at $200 \mathrm{mmHg}$ of vacuum and $229 \mathrm{~W}$ of microwave power with different final moisture contents were used to investigate the growth of the microorganisms after drying. Table 3 shows the results of the growth of mesophilic bacteria in the acerola residue over time at different moisture contents and the respective values of water activity $\left(A_{w}\right)$. 
Table 3

- Growth* of mesophilic bacteria in the residue of acerola over time.

\begin{tabular}{|c|c|c|c|c|c|c|c|c|c|c|}
\hline \multirow{2}{*}{$\begin{array}{l}\text { Moisture } \\
\text { content } \\
(\%, w b)\end{array}$} & \multicolumn{9}{|c|}{ Weeks } & \multirow[t]{2}{*}{$A_{W(-)}$} \\
\hline & 1 & 2 & 3 & 4 & 8 & 12 & 16 & 20 & 24 & \\
\hline 3,7 & ND & ND & ND & ND & ND & ND & ND & ND & ND & $0.181 \pm 0.029$ \\
\hline 19,4 & ND & ND & ND & ND & ND & ND & ND & ND & ND & $0.807 \pm 0.007$ \\
\hline 26,2 & ND & ND & ND & ND & ND & ND & ND & ND & ND & $0.897 \pm 0.012$ \\
\hline 47,7 & $\begin{array}{l}1.42 \\
\times 10^{3}\end{array}$ & $\begin{array}{l}1.71 \\
\times 10^{3}\end{array}$ & $\begin{array}{l}3.40 \\
\times 10^{3}\end{array}$ & $\begin{array}{l}9.08 \\
\times 10^{3}\end{array}$ & - & - & - & - & - & $0962 \pm 0.002$ \\
\hline 66,9 & $\begin{array}{r}5.13 \\
\times 10^{3}\end{array}$ & $\begin{array}{l}5.75 \\
\times 10^{3}\end{array}$ & $\begin{array}{r}1.55 \\
\times 10^{4}\end{array}$ & $\begin{array}{l}2.81 \\
\times 10^{4}\end{array}$ & - & - & - & - & - & $0.970 \pm 0.005$ \\
\hline
\end{tabular}

The acerola residue with moisture content lower than $26.2 \%(\mathrm{wb})$ did not present a favorable environment for the development of mesophilic bacteria within the period of 24 weeks (six months). For the material with moisture contents of 47.7 and $66.9 \%$ (wet basis), the experiments were interrupted after the 4th week, as exponential growth of these microorganisms had already been detected.

The results of mold and yeast growth in the acerola residue over time at different moisture contents and the respective water activities $\left(A_{w}\right)$ are presented in Table 4. Again, the acerola residue with moisture content lower than $26.2 \%(\mathrm{wb})$ did not present a favorable environment for mold and yeast growth within six months. The counting of molds and yeasts is applicable mainly in the analysis of acidic and partially dehydrated foods. Their presence at higher rates indicates flaws in the food processing and/or storage [66]. 
Table 4

- Growth* of molds and yeasts in the residue of acerola over time.

\begin{tabular}{|c|c|c|c|c|c|c|c|c|c|c|}
\hline \multirow{2}{*}{$\begin{array}{l}\text { Moisture } \\
\text { content } \\
(\%, w b)\end{array}$} & \multicolumn{9}{|c|}{ Weeks } & \multirow[t]{2}{*}{$A_{W(-)}$} \\
\hline & 1 & 2 & 3 & 4 & 8 & 12 & 16 & 20 & 24 & \\
\hline 3,7 & ND & ND & ND & ND & ND & ND & ND & ND & ND & $0.181 \pm 0.029$ \\
\hline 19,4 & ND & ND & ND & ND & ND & ND & ND & ND & ND & $0.807 \pm 0.007$ \\
\hline 26,2 & ND & ND & ND & ND & ND & ND & ND & ND & ND & $0.897 \pm 0.012$ \\
\hline 47,7 & $\begin{array}{l}1.26 \\
\times 10^{3}\end{array}$ & $\begin{array}{l}2.20 \\
\times 10^{3}\end{array}$ & $\begin{array}{l}4.20 \\
\times 10^{3}\end{array}$ & $\begin{array}{l}8.00 \\
\times 10^{3}\end{array}$ & - & - & - & - & - & $0962 \pm 0.002$ \\
\hline 66,9 & $\begin{array}{l}3.22 \\
\times 10^{3}\end{array}$ & $\begin{array}{l}7.55 \\
\times 10^{4}\end{array}$ & $\begin{array}{l}1.85 \\
\times 10^{5}\end{array}$ & $\begin{array}{l}6.80 \\
\times 10^{5}\end{array}$ & - & - & - & - & - & $0.970 \pm 0.005$ \\
\hline
\end{tabular}

$A_{w}$ is an important parameter to identify conditions for the growth of pathogenic microorganisms. ${ }^{[6]}$ The initial $A_{w}$ of the fresh sample was and $0.973 \pm 0.001$, whereas for the final moistures analyzed in this study the $A_{w}$ of the dried samples ranged between 0.181 and 0.970 . At $26.2 \%(w b)$, the $A_{w}$ was $0.897 \pm 0.002$, and below this value there was no further growth of microorganisms. Our findings are in good agreement with Chua et al. [67], who stated that most food spoilage by bacteria is inhibited by $A_{w}$ below 0.91 . Therefore, acerola residues with moisture contents below $26.2 \%(\mathrm{wb})$ can be considered shelf stable to microbial growth.

\section{Conclusions}

The vacuum microwave device investigated herein proved to be a promising hybrid technology able to maintain the quality of acerola residues, prolonging their shelf life and providing safe moisture and water activity levels. The effects of vacuum level, microwave power and ethanol pretreatment on the main bioactive compounds after drying were successfully investigated. Among the studied variables, the pretreatment with ethanol had the highest effect on the main bioactive compounds, leading to an increase in ascorbic acid (AA) and a decrease in total phenolic content (TPC). However, the values obtained for the bioactive compounds after drying could be classified as intermediate concentrations, according to the classification of Vasco et al. (2008), thus showing a good potential to be used as food additives. The growth of mesophilic bacteria, molds, and yeasts in acerola residues was not observed for the dried material at a final moisture content below $26.2 \%(\mathrm{wb})$.

\section{Abbreviations}




\begin{tabular}{|c|c|c|}
\hline AA & Ascorbic acid content & (mg $100 \mathrm{~g}^{-1}$ of sample, dry matter) \\
\hline Aw & Water activity & $(-)$ \\
\hline CFU & Colony Forming Units & (CFU g ${ }^{-1}$ acerola residue) \\
\hline $\mathrm{db}$ & Dry basis & \\
\hline EP & Preteatment without ethanol & \\
\hline HPLC & $\begin{array}{l}\text { High Performance Liquid } \\
\text { Chromatography }\end{array}$ & \\
\hline MR & Moisture ratio & $(-)$ \\
\hline $\mathrm{MR}_{\text {exp,i }}$ & Experimental moisture ratio & $(-)$ \\
\hline $\mathrm{MR}_{\mathrm{pre}, \mathrm{i}}$ & Predicted moisture ratio & $(-)$ \\
\hline M & Moisture content at any time & ( $\mathrm{g} \mathrm{H}_{2} \mathrm{O} 100 \mathrm{~g}^{-1}$ dry matter) \\
\hline$M_{0}$ & Initial moisture content & ( $\mathrm{g} \mathrm{H}_{2} \mathrm{O} 100 \mathrm{~g}^{-1}$ dry matter) \\
\hline $\mathrm{M}_{\mathrm{eq}}$ & Equilibrium moisture content & ( $\mathrm{g} \mathrm{H}_{2} \mathrm{O} 100 \mathrm{~g}^{-1}$ dry matter) \\
\hline$N$ & Number of observations & \\
\hline$P$ & Microwave power & $(W)$ \\
\hline PCA & Plate Count Agar & \\
\hline PDA & Potato Dextrose Agar & \\
\hline $\mathrm{RH}$ & Relative humidity & $(-)$ \\
\hline $\mathrm{R}^{2}$ & Determination of coefficient & $(\%)$ \\
\hline RMSE & Root mean square residuals & $(-)$ \\
\hline$T$ & Air temperature & $\left({ }^{\circ} \mathrm{C}\right)$ \\
\hline TFC & Total flavonoids content & (mg of rutin $100 \mathrm{~g}^{-1}$ of sample, dry matter) \\
\hline TPC & Total phenolic content & $\begin{array}{l}\text { (mg of gallic acid equivalent } 100 \mathrm{~g}^{-1} \text { of sample, dry } \\
\text { matter) }\end{array}$ \\
\hline$V$ & Vacuum & $(\mathrm{mmHg})$ \\
\hline$\chi^{2}$ & Reduced qui-square & $(-)$ \\
\hline z & Number of constants & \\
\hline
\end{tabular}

\section{Declarations}


Acknowledgements

The authors are thankful for the financial support of the Brazilian research funding agencies, the Coordination for the Improvement of Higher Education Personnel (CAPES), the Brazilian National Council for Scientific and Technological Development (CNPq), and the Research Support Foundation of the state of Minas Gerais (FAPEMIG).

\section{Conflict of Interest}

The authors declare that they have no known competing financial interests or personal relationships that could have appeared to influence the work reported in this paper.

\section{Data Availability}

The datasets generated during the current study are available from the corresponding author on reasonable request.

\section{References}

1. Ramadan, L., Duarte, C.R., Barrozo, M.A.S.: A new hybrid system for reuse of agro-industrial wastes of acerola: dehydration and fluid dynamic analysis. Waste BiomassValoriz 10, 2273-2283 (2019)

2. Garcia, G.G., Woolley, E., Rahimifard, S., Colwill, J., White, R., Needham, L.A.: Methodology for sustainable management of food waste. Waste Biomass Valor 8, 2209-2227 (2017)

3. Silva, D.I.S., Silva, N.C., Mendes, L.G., Barrozo, M.A.S.: Effects of thick-layer drying on the bioactive compounds of acerola residues. J. Food Process Eng 41, 1-10 (2018)

4. Silva, P.B., Nogueira, G.D.R., Duarte, C.R., Barrozo, M.A.S.: A New Rotary Dryer Assisted by Infrared Radiation for Drying of Acerola Residues. Waste Biomass Valoriz 12, 3395-3406 (2021)

5. Silva, N.C., Duarte, C.R., Barrozo, M.A.S.: Effects of dehydration methods on quality characteristics of yellow passion fruit coproducts. J. Sci. Food Agric. 97, 4750-4759 (2017)

6. Onoja, E., Chandren, S., Abdul Razak, F.I., Mahat, N.A., Wahab, R.A.: Oil palm (Elaeis guineensis) biomass in Malaysia: the presente and future prospects. Waste Biomass Valoriz. 10, 2099-2117 (2018)

7. Pande, H., Kumar, B., Varshney, V.K.: Phenolic composition and antioxidant capacity of biomass residue (leaves) generated from Bambusa tulda plantations. Waste Biomass Valor 8, 2349-2362 (2017)

8. Notermans, S., Heuvelman, C.J.: Combined effect of water activity, $\mathrm{pH}$ and sub-optimal temperature on growth and enterotoxin production of Staphylococcus aureus. J. Food Sci. 48, 1832-1835 (1983)

9. Ibarz, A., Barbosa-Canovás, G.V.: Unit Operations in Food Engeneering. CRC Press, Boca Raton (2002)

10. Pasteni, A., Uribe, E., Stucken, K., Rodriguez, A., Galvez, A.V.: Influence of drying on the recoverable high-value products from olive (cv. Arbequina) waste cake. Waste Biomass Valoriz. 10, 1627-1638 
(2019)

11. Hii, C.L., Ong, S.P., Yap, J.Y., Putranto, A., Mangindaan, D.: Hybrid drying of food and bioproducts: A review. Drying Technol. 39, 1554-1576 (2021)

12. Silva, D.I.S. Study of the heat and mass transfer in a fixed bed dryer aiming the reuse of residues of acerola (Malpighia emarginata D.C.). PhD Thesis, Federal University of Uberlândia: (2015)

13. Barrozo, M.A.S., Murata, V.V., Costa, S.M.: The drying of soybean seeds in countercurrent and concurrent moving bed dryers. Drying Technol. 16, 2033-2047 (1998)

14. Freire, F.B., Barrozo, M.A.S., Sartori, D.J.M., Freire, J.T.: Study of the drying kinetics in thin layer: Fixed and moving bed. Drying Technol. 23, 1451-1464 (2005)

15. Barrozo, M.A.S., Henrique, H.M., Sartori, D.J.M., Freire, J.T.: The use of the orthogonal collocation method on the study of the drying kinetics of soybean seeds. J. Stored Prod. Res. 42, 348-356 (2006)

16. Silva, D.O., Tamiozzo, L.M., Duarte, C.R., Murata, V.V., Barrozo, M.A.S.: Modeling of seed coating in spouted bed. Dry.Technol. 29, 286-294 (2011)

17. Barrozo, M.A.S., Mujumdar, A., Freire, J.T.: Air-Drying of Seeds: A Review. Drying Technol. 32, 11271141 (2014)

18. Acar, C., Dincer, I., Mujumdar, A.: A comprehensive review of recent advances in renewable-based drying technologies for a sustainable future. Drying Technol. (2020) https://doi.org/10.1080/07373937.2020.1848858

19. Silva, P.B., Duarte, C.R., Barrozo, M.A.S.: A novel system for drying of agro-industrial acerola (Malpighia emarginata D. C.) waste for use as bioactive compound source. Innov. Food Sci. Emerg. Technol. 52, 350-357 (2019)

20. Wang, L., Zhao, Y., Ma, W., Shen, L., Liu, C., Liu, C., Zheng, X., Li, S.: Utilization efficiency of microwave energy for granular food in continuous drying: From propagation properties to technology parameters. Drying Technol. (2021) https://doi.org/10.1080/07373937.2021.1890770

21. Ghasemi, A., Chayjan, R.A.: Optimization of pelleting and infrared-convection drying processes of food and agricultural waste using response surface methodology (RSM). Waste Biomass Valoriz. 10, 1711-1729 (2019)

22. Mekki, A., Arous, F., Aloui, F., Sayadi, S.: Treatment and valorization of agro-wastes as biofertilizers. Waste Biomass Valor 8, 611-619 (2017)

23. Souza, G.F.M.V., Miranda, R.F., Barrozo, M.A.S.: Soybean (Glycine max L. Merrill) seed drying in fixed bed: process heterogeneity and seed quality. Drying Technol. 33, 1779-1787 (2015)

24. Silva, D.I.S., Souza, G.F.M.V., Barrozo, M.A.S.: Heat and mass transfer of fruit residues in a fixed bed dryer: Modeling and product quality. Drying Technol. 37, 1321-1327 (2018)

25. Nogueira, G.D.R., Silva, P.B., Duarte, C.R., Barrozo, M.A.S.: Analysis of a hybrid packed bed dryer assisted by infrared radiation for processing acerola (Malpighia emarginata D.C.) residue. Food Bioprod. Process. 114, 235-244 (2019) 
26. Kalla, A.M., Devaraju, R.: Microwave energy and its application in food industry: A review. Asian J. Dairy Food Res. 36, 37-44 (2017)

27. Béttega, R., Rosa, J.G., Corrêa, R.G., Freire, J.T.: Comparison of carrot (Daucus carota L) drying in microwave and in vaccum microwave. Braz. J. Chem. Eng. 31, 403-412 (2014)

28. Lech, K., Figiel, A., Wojdyło, A., Korzeniowska, M., Serowik, M., Szarycz, M.: Drying kinetics and bioactivity of beetroot slices pretreated in concentrated chokeberry juice and dried with vacuum microwaves. Drying Technol. 33, 1644-1653 (2015)

29. Zielinska, M., Sadowski, P., Błaszczak, W.: Combined hot air convective drying and microwavevacuum drying of blueberries (Vaccinium corymbosum L.): Drying kinetics and quality characteristics. Drying Technol. 34, 665-684 (2016)

30. Jia, X., Clements, S., Jolly, P.: Study of heat pump assisted microwave drying. Drying Technol. 11, 1583-1616 (1993)

31. Lyu, J., Bi, J., Wang, F., Jin, X., Wu, X., Xie, J.: Recent developments and trends of instant controlled pressure drop drying - A review. Drying Technol. 39, 1704-1719 (2021)

32. Jaya, S., Das, H.: A vacuum drying model for mango pulp. Drying Technol. 21, 1215-1234 (2003)

33. Chen, F., Zhang, M., Mujumdar, A.S., Jiang, H., Wang, L.: Production of crispy granules of fish: a comparative study of alternate drying techniques. Drying Technol. 32, 1512-1521 (2014)

34. Mounir, S., Ghandour, A., Téllez-Pérez, C., Aly, A.A., Mujumdar, A.S., Allaf, K.: Phytochemicals, chlorophyll pigments, antioxidant activity, relative expansion ratio, and microstructure of dried okra pods: swell-drying by instant controlled pressure drop versus conventional shade drying. Drying Technol. (2020) https://doi.org/10.1080/07373937.2020.1756843

35. Cao, X., Zhang, M., Mujumdar, A.S., Wang, Z.: Effect of microwave freeze-drying on microbial inactivation, antioxidant substance and flavor quality of Ashitaba leaves (Angelica keiskei Koidzumi). Drying Technol. 37, 793-800 (2019)

36. Yaghmaee, P., Durance, T.: Efficacy of vacuum microwave drying in microbial decontamination of dried vegetables. Drying Technol. 25, 1099-1104 (2007)

37. Karathanos, V.T., Kostaropoulos, A.E., Saravacos, G.D.: Air-drying kinetics of osmotically dehydrated fruits. Drying Technol. 13, 1503-1521 (1995)

38. Islam, M., Zhang, M., Fan, D.: Ultrasonically enhanced low-temperature microwave-assisted vacuum frying of edamame: Effects on dehydration kinetics and improved quality attributes. Drying Technol. $37,2087-2104(2019)$

39. Zhou, C., Cai, Z., Wang, X., Feng, Y., Xu, X., Yagoub, A.E.A., Wahia, H., Ma, H., Sun, Y.: Effects of trifrequency ultrasonic vacuum-assisted ethanol pretreatment on infrared drying efficiency, qualities and microbial safety of scallion stalk slices. Drying Technol. (2021) https://doi.org/10.1080/07373937.2021.1894572

40. Silva, P.B., Duarte, C.R., Barrozo, M.A.S.: Dehydration of acerola (Malpighia emarginata D.C.) residue in a new designed rotary dryer: Effect of process variables on main bioactive compounds. Food Bioprod. Process. 98, 62-70 (2016) 
41. Cunha, R.M.C., Brandão, S.C.R., Medeiros, R.A.B., Silva Júnior, E.V., Silva, J.H.F., Azoubel, P.M.: Effect of ethanol pretreatment on melon convective drying. Food Chem. 333, 1-7 (2020)

42. Herppich, W.B., Huyskens-Keil, S., Hassenberg, K.: Impact of ethanol treatment on the chemical properties of cell walls and their influence on toughness of white Asparagus (Asparagus officinalis L.) spears. Food Bioprocess Technol. 8, 1476-1484 (2015)

43. Fernandes, F.A.N., Gallão, M.I., Rodrigues, S.: Effect ofosmotic dehydration and ultrasound pretreatment on cellstructure: melon dehydration. LWT-Food Sci. Technol. 41, 604-610 (2008)

44. Arruda, E.B., Lobato, F.S., Assis, A.J., Barrozo, M.A.S.: Modeling of fertilizer drying in roto-aerated and conventional rotary dryers. Drying Technol. 27, 1192-1198 (2009)

45. Lobato, F.S., Steffen, V. Jr., Arruda, E.B., Barrozo, M.A.S.: Estimation of drying parameters in rotary dryers using differential evolution. J. Phys. Conf. Ser. (2008) https://doi.org/10.1088/17426596/135/1/012063

46. Conceição Filho, R.S., Barrozo, M.A.S., Limaverde, J.R., Ataíde, C.H.: The use of a spouted bed in the fertilizer coating of soybean seeds. Drying Technol. 16, 2049-2064 (1998)

47. Duarte, C.R., Vieira Neto, J.L., Lisboa, M.H., Santana, R.C., Barrozo, M.A.S., Murata, V.V.: Experimental study and simulation of mass distribution of the covering layer of soybean seeds coated in a spouted bed. Braz. J. Chem. Eng. 21, 59-67 (2004)

48. Dürüst, N., Sümengen, D., Dürüst, Y.: Ascorbic acid and element contents of food of trabzon (Turkey). J. Agric. Food Chem. 45, 2085-2087 (1997)

49. Singleton, V.L., Rossi, J.A. Jr.: Colorimetry of total phenolic swith phosphomolybdic-phosphotungstic acid reagents. Am. J. Enol. Vitic. 16, 144-158 (1965)

50. Zhishen, J., Mengcheng, T., Jianming, W.: The determination of flavonoid contents in mulberry and their scavenging effects on superoxide radicals. Food Chem. 64, 555- 559 (1999)

51. Box, M.J., Hunter, W.G., Hunter, J.S.: Statistics for experimenters: An introduction to design, data analysis, and model building. John Wiley and Sons, New York (1978)

52. Doymaz, İ, İsmail, O.: Drying characteristics of sweet cherry. Food Bioprod. Process. 89, 31-38 (2011)

53. International Organization for Standardization - ISO. Microbiology of food and animal feeding stuffs - Preparation of test samples, initial suspension and decimal dilutions for the microbiological examination - Part 4: Specific rules for the preparation of products other than milk and milk products, meat and meat products and fish and fishery products, Geneva: (2003) (EN ISO 6887-4:2003)

54. Silva, N., Junqueira, V.C.A., Silveira, N.F.A., Taniwaki, M.H., Santos, R.F.S., Gomes, R.A.R.: Manual of Methods for Microbiological Analysis of Food and Water, 4ª . ed. Varela Bookstore, São Paulo (2010)

55. Pinheiro, A.M., Fernandes, A.G., Fai, A.E.C., Prado, G.D., Sousa, P.D., Maia, G.A.: Chemical, physicochemical and microbiological evaluation of whole fruit juices: pineapple, cashew and passion fruit. Food Sci. Technol. 26, 98-103 (2006)

56. Wojdyło, A., Figiel, A., Lech, K., Nowicka, P., Oszmiański, J.: Effect of convective and vacuummicrowave drying on the bioactive compounds, color, and antioxidant capacity of sour cherries. Food 
and Bioproc. Tech. 7, 829-841: (2014)

57. Cui, Z.W., Xu, S.Y., Sun, D.W.: Microwave-vacuum drying kinetics of carrot slices. J. Food Eng. 65, 157-164 (2004)

58. Funebo, T., Ahrné, L., Prothon, F., Kidman, S., Langton, M., Skjöldebrand, C.: Microwave and convective dehydration of ethanol treated and frozen apple-physical properties and drying kinetics. Int. J. Food Sci. Technol. 37, 603-614 (2002)

59. Dorta, E., Lobo, M.G., González, M.: Using drying treatments to stabilise mango peel and seed: Effect on antioxidant activity. LWT - Food Sci. Technol. 45, 261-268 (2012)

60. Alibas, l., Köksal, N.: Convective, vacuum and microwave drying kinetics of mallow leaves and comparison of color and ascorbic acid values of three drying methods. Food Sci. Technol. 34, 358364 (2014)

61. Zhang, M., Tang, J., Mujumdar, A.S., Wang, S.: Trends in microwave-related drying of fruits and vegetables. Trends in Food Sci. Technol. 17, 524-534 (2006)

62. Thomkapanich, O., Suvarnakuta, P., Devahastin, S.: Study of intermittent low-pressure superheated steam and vacuum drying of a heat-sensitive material. Drying Technol. 25, 205-223 (2007)

63. Wojdyło, A., Figiel, A., Oszmiański, J.: Effect of drying methods with the application of vacuum microwaves on the bioactive compounds, color, and antioxidant activity of strawberry fruits. J. Agric. Food Chem. 57, 1337-1343 (2009)

64. Orphanides, A., Goulas, V., Gekas, V.: Effect of drying method on the phenolic content and antioxidant capacity of spearmint. Czech J. Food Sci. 31, 509-513 (2013)

65. Vasco, C., Ruales, J., Kamal-Eldin, A.: Total phenolic compounds and antioxidant capacities of major fruits from Ecuador. Food Chem. 111, 816-823 (2008)

66. Siqueira, R.S.: Food Microbiology Manual. EMBRAPA, SPI; Rio de Janeiro, Brasília (1995) EMBRAPA, CTAA

67. Chua, L.Y.W., Chua, B.L., Figiel, A., Chong, C.H., Wojdylo, A., Szumnyy, A., Choong, T.S.Y.: Antioxidant activity, and volatile and phytosterol contents of strobilanthes crispus dehydrated using conventional and vacuum microwave drying methods. Molecules 24, 1-21 (2019)

\section{Unsectioned Figure Details}

A

Fig. 1

Drying curves at vacuum of $200 \mathrm{mmHg}$ : experimental data and predicted values by Overhults equation.

(a) Without EP; (b) with EP

A

Fig. 2 
Temperature evolution of acerola residues during vacuum microwave drying at a power output of $229 \mathrm{~W}$ : (a) Non-treated; (b) pretreated with ethanol

A

Fig. 3

Ascorbic Acid content after drying: (a) power effect on experiments at $200 \mathrm{mmHg}$ of vacuum applied; (b) vacuum effect on experiments at a microwave power of $229 \mathrm{~W}$

A

Fig. 4

Total Phenolic Content after drying: (a) power effect on experiments at $200 \mathrm{mmHg}$ of vacuum applied; (b) vacuum effect on experiments at a microwave power of $229 \mathrm{~W}$

A

Fig. 5

Total Flavonoid Content after drying: (a) power effect on experiments at $200 \mathrm{mmHg}$ of vacuum applied; (b) vacuum effect on experiments at a microwave power of $229 \mathrm{~W}$

Figures
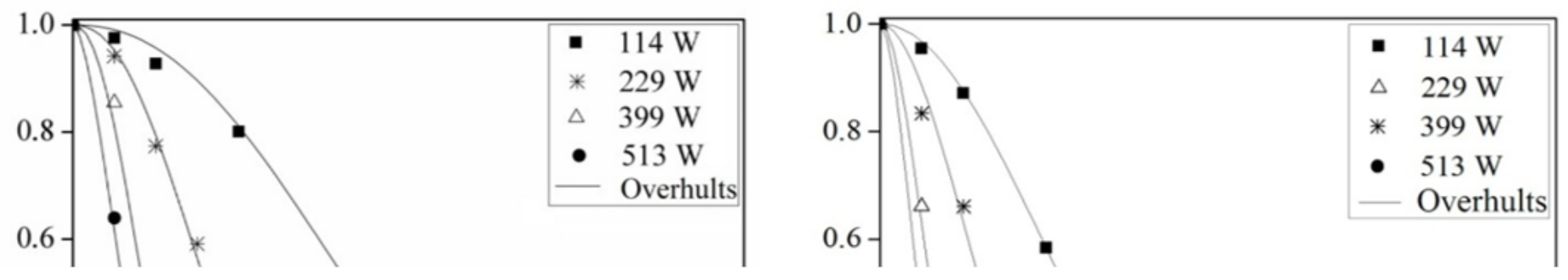

Figure 1

Drying curves at vacuum of $200 \mathrm{mmHg}$ : experimental data and predicted values by Overhults equation. (a) Without EP; (b) with EP 


\section{Figure 2}

Temperature evolution of acerola residues during vacuum microwave drying at a power output of $229 \mathrm{~W}$ : (a) Non-treated; (b) pretreated with ethanol

(a)

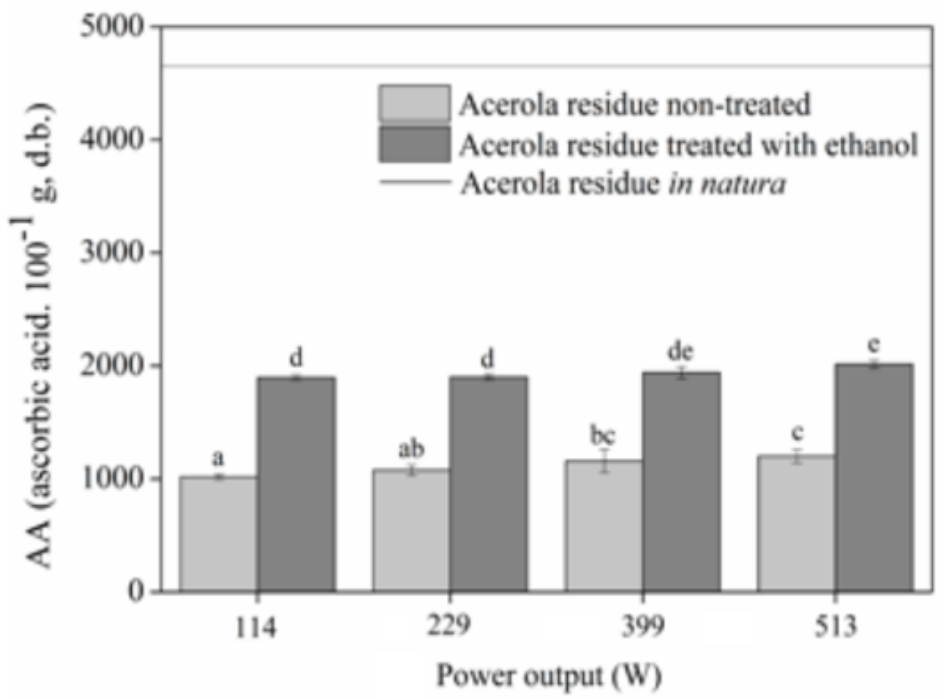

(b)

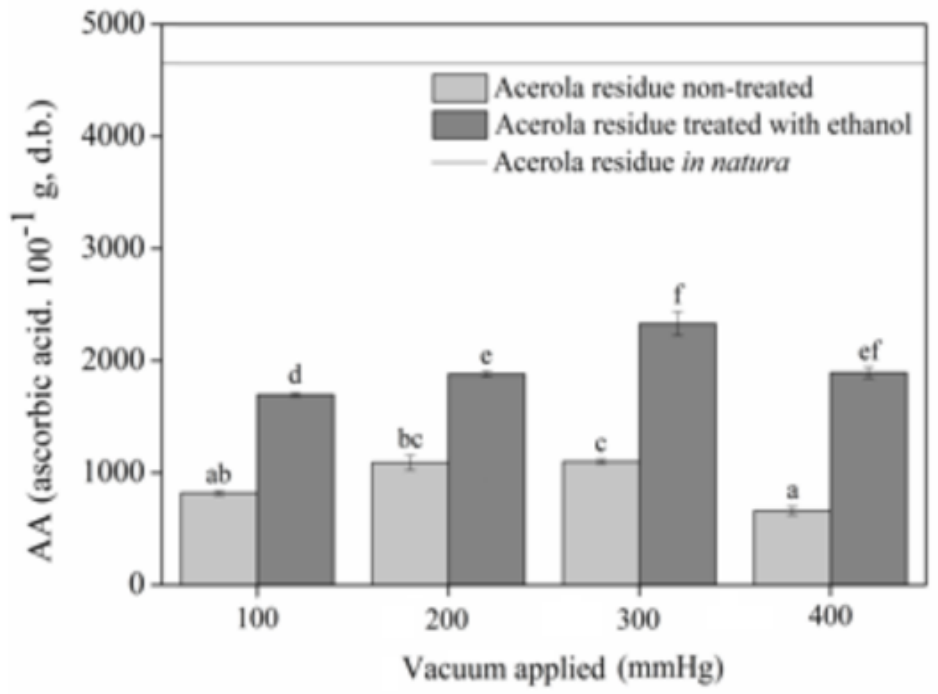

\section{Figure 3}

Ascorbic Acid content after drying: (a) power effect on experiments at $200 \mathrm{mmHg}$ of vacuum applied; (b) vacuum effect on experiments at a microwave power of $229 \mathrm{~W}$

Values represent means \pm standard deviation. Values with the same letters in different columns are no significantly different at

$p<0.05$ (Tukey's HSD test). All determinations were performed in triplicate. 
(a)

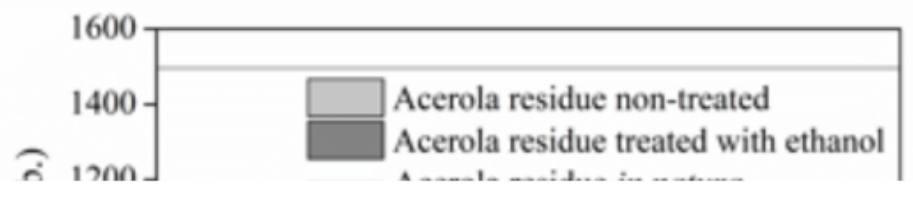

(b)

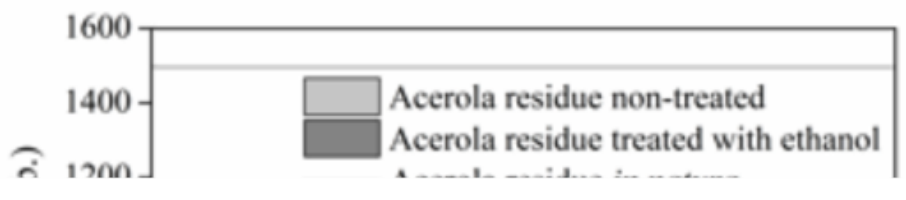

\section{Figure 4}

Total Phenolic Content after drying: (a) power effect on experiments at $200 \mathrm{mmHg}$ of vacuum applied; (b) vacuum effect on experiments at a microwave power of $229 \mathrm{~W}$

Values represent means \pm standard deviation. Values with different letters in the same column are significantly different at $p<0.05$ (Tukey's HSD test). All determinations were performed in triplicate.

\section{Figure 5}

Total Flavonoid Content after drying: (a) power effect on experiments at $200 \mathrm{mmHg}$ of vacuum applied; (b) vacuum effect on experiments at a microwave power of $229 \mathrm{~W}$

Values represent means \pm standard deviation. Values with different letters in the same column are significantly different at $p<0.05$ (Tukey's HSD test). All determinations were performed in triplicate.

\section{Supplementary Files}

This is a list of supplementary files associated with this preprint. Click to download.

- GraphicalAbstract.png 